\title{
Sociodrama Method; Stimulate the Development of Attitudes, Knowledge and Skills of Students in Excellent Service Learning
}

\author{
Brillian Rosy \\ The Faculty Of Economics Universitas Negeri Surabaya \\ Email : brillianrosy@unesa.ac.id
}

\begin{abstract}
Implementation of the Curriculum 2013 expects students not only memorize the theory, but is expected to practice it or apply it to gain knowledge, skills and attitude development so that the quality of education to be good. There are some materials in Service Excellence subject, among others are as follows: a) Standard of Personal Appearance, b) Prime Service Principle, c) Providing Help to Customers, and d) Communication with Customers. However, some knowledge materials in the Excellent Service such as how to provide assistance to customers and communicate with customers are difficult to understand by students when teachers explain by lecture method. This can hamper the creativity and skill of the students because the learning only takes one direction, while the material presented is the material that is practical and demands the skills of the students. Direct practice or demonstration is meant for students to imagine and feel as though they are in real situations when the excellent service is performed. Learning process like this, requires a learning method that can support the learning objectives. The Sociodrama method is a teaching method in which the teacher provides the opportunity for the pupil to perform certain role playing activities as found in the life of the social community. The conceptual review in this article proves that the Sociodrama method has successfully stimulated the development of students' attitudes, knowledge and skills in Learning service excellence.
\end{abstract}

Keywords: Learning Model, Sociodrama, Excellent Service

The essence of education is an effort to develop the potential of human beings, so that human is capable of facing any change towards a better direction. This is in accordance with the purpose of national education in UU No. 20 Tahun 2003 Pasal 3, as follows: "Pendidikan Nasional berfungsi mengembangkan kemampuan dan pembentukan watak serta peradaban bangsa yang bermartabat dalam rangka mencerdaskan kehidupan bangsa bertujuan untuk berkembangnya potensi peserta didik agar menjadi manusia yang beriman dan bertakwa kepada Tuhan YME, berakhlak mulia, sehat, berilmu, cakap, kreatif, mandiri, dan menjadi warga negara yang demokratis serta bertanggungjawab".

In education, the role of curriculum is very strategic in in achieving the goals of National Education. Currently implemented is the curriculum 2013 which covers three competence such as others competence of attitudes, knowledge, and 
integrated. Education of character or attitude is very important. In his book, Koesoma (2007: 132-133) write "Dalam masyarakat yang mulai hilang nilai-nilai dan moralitas, pendidikan sikap adalah momentum yang tepat untuk bangkit". Education of character has a very strategic and effective function in the process of social change in society if done in a planned manner.

Furthermore, the competencies of knowledge, knowledge is meant here is lead to the understanding of students in learning. According to Ramelan (2008: 74), Explains that understanding is an intellectual skill that shows the knowledge of what is "said" in verbal form, images and symbols. According to Maryati dan Suryawati (2006: 123), "Pengetahuan adalah segala sesuatu yang diketahui manusia tentang benda, sifat, keadaan dan harapan-harapan". Knowledge gained through experience, intuition, logic, revelation, or trial activities (trial and error). The importance of knowledge for life is very large. When humans have been able to develop what their thinking, human will be able to develop knowledge. Humans develop knowledge because it is not just to carry out his life with the knowledge will be able to make people overcome problems present in his life.

Skills are often misunderstood by some people. Many people connect skills with ability or physical skills or motion (motoric). Skills expected in the Curriculum 2013 is a very broad skills that is the process skills to develop their knowledge. Someone who has a vast knowledge not necessarily have the skills and vice versa. Therefore why in Curriculum 2013 besides aspects of knowledge, skill aspect also needs to be highlighted more. So the students not only memorize the material but understand.

In the structure of the curriculum of Sekolah Menengah Kejuruan (SMK), there is the productive subjects namely, excellent service. The subjects of excellent service are training which equip students how to ways to do so that customers are satisfied with the service provided (Utami, 2014). These subjects are very important and necessary when the students undergo internship or OJT (On the Job Training). Not only that, in the era of MEA which level of competition will be more intense, companies are required to have employees who have the ability to serve customers well. For this reason, students are required to be able to provide excellent service wherever and whenever. This is due to the competition that must be faced by students when in the working world will be very high because a lot of labor from overseas will go to Indonesia.

Excellent service is usually closely related to business services being performed in an attempt to give a sense of confidence and growing satisfied customers or consumers, so customers feels important or cared for properly and correctly. The importance of excellent service towards customers is also a strategy in order to win the competition. However, it is not enough to just give a sense of satisfaction and attention to customers, more than that is how to respond to the desires of customers, so as to give rise to a positive impression of the customer.

Excellent service have to supported by human resource quality is reliable, has a vision that far into the future and can develop strategies and tips for excellent service which has primacy. In addition, it should be continuously strived to improve the ability of the officers of of service officers in order to foster attitudes (dedication) and provide the best service to customers to remain loyal to 
use the product of our goods and services, no longer had time to glance or use other product.

There is some material in the subjects of excellent service, among which are as following: a Personal Appearance Standards), b) principles of excellent service, c) provide assistance to customers, and d) Communicate with customers. But some of the material the knowledge in excellent service which is difficult to be understood by the learners when the teacher explains the method of ordinary lectures. This is because the materials require examples of real practice as understanding how to provide assistance to customers and communicate with customers. When this material only attested through the lecture method, it can inhibit the power of creativity and skills of learners because the lesson only lasted one way, while the material presented is a material that is practical and requires the skills of students.

Direct practice or demonstration becomes the important thing in these subjects in order to spur creativity and imaginative power of students. The demonstration was intended to students can imagine and feel as if they are in a real situation when such excellent service done. Once students can imagine, the next step to do the teacher is to guide students to not merely imagined, but it can do excellent service in accordance with the situation in the field. To be able to run a learning process such as this, then needed a method of learning that can support the learning objectives.

Learning method is a planning or a pattern used as a guide in planning the learning in the classroom (Utami, 2014). In principle, none of the methods that is perfect or match on the subject in every subject of study. Because each method have excellent and weakness of each. Therefore, teachers should not arbitrarily choose and use methods. Based on the purpose of learning excellent Services subjects, then a suitable learning method is sociodrama learning method.

According to Winkel (2005), Sociodrama is a dramatization of the various issues that can arise in association with others, including conflicts that are often experienced in social intercourse. The opinion in line with Djamarah (20010:200) stating that the method of Sociodrama is a way of teaching that provides opportunities for students doing a particular role that exists in the community. The Sociodrama method is a method of teaching where the teacher gives the opportunity to students to perform a certain role, such as that contained in the social life of the community. By using the Sociodrama method, learners are expected to take an active role in the learning process and can master the material optimally.

Based on the above background, then this article to formulate how Sociodrama method can be to stimulate the development of attitude, knowledge and skills of students in excellent service learning, who are expected to provide benefits to readers. 


\section{RESULTS \& DISCUSSION}

\section{Learning Methods}

Learning methods is a way used by educators to learners with the effort to achieve a particular goal. Here are the things considered in selecting and determining methods of learning:

a. Strategic value method

The subject matter conveyed without using the method will be difficult for teachers to achieve learning objectives. Experience proves the failure of learning one of these are caused by less precise method selection. It corresponds to the explanation of Djamarah (2010:76), that the class is less passionate with the condition of the learners who are less creative because of the determination of the methods are less accordance with the nature of the materials and not in accordance with the purpose of teaching. So, it can be concluded that the method was a way that have strategic value in teaching and learning activities. The strategic value is the method can affect the course of learning, therefore the teacher should pay attention in selection and determination of methods before learning.

b. effectiveness of the use of method

The use of methods that do not accordance with the purpose of learning will be a constraint in achieving learning objectives (Djamarah 2010:78). The subject matter presented in vain because of the use of methods according to the will of the teacher and student needs are ignored, facilities and the situation of the class. For example, teachers who use the lecture method in material of customer communications while the purpose of the learning was so that students are skilful to communicate, is less conducive learning activities. Should the use of the method must to show the achievement of learning objectives, not a goal that adjusts with the method. Therefore, the effectiveness of the use of methods can occur when there is a conformity between methods with all components of teaching that have been added.

c. The importance of the election and the determination of the method teacher as one resources of learning obligated to provides an conducive environment to learning activity of learners in the class. One of the activities that teacher had to do selection and determination of the effective methods to achieve learning objectives. Selection and determination of this method is based on the existence of certain methods could not be used to achieve a specific learning goal. For example, the purpose of learning is so that students can master the attitude competence, knowledge and skills on the material provide assistance to customers, then the teacher can not use the learning method of Picture and Picture, but the right is the Sociodrama Method. In the sociodrama method students were taught to dare to move in front of the class by eliminating shame and can also train the responsibility.

Based on the above exposure then it can be understood that the failure in reaching the learning objectives can be avoided when it first knowing of the shortcomings and advantages of each method before using it. 


\section{Sociodrama Method}

Sociodrama is composed of two syllables "socio" meaning society, and "drama" which means one's circumstances or events experienced by people, nature and the behavior, the relationship of a person, a person's relationships with others and so on. The Sociodrama method is a method of teaching where the teacher gives the opportunity to students to perform a certain role, such as that contained in the social life of the society. In its application through demonstration or modeled someone (students) that accordance with the flow and the same character with the contents of the material taught, and represented or exemplified by friends in class, so judged (not that judging the character of the child but the judge in his role) to know how to fill in the role, a point the emphasis lies in the emotional involvement and sense observations into a situation in the real problems faced by students.

The study by the Sociodrama method, characterization not done completely until the problem can be solved. It is intended to invites a sense of students which became an observer in order to particapte actively discuss and find a solutions. Thus, discussion after playing the role of will take place live and exciting learners. This concept in accordance with the opinion of the Sociodrama suggests that some of useful to instill the ability to analyze a specific social situation. In this Sociodrama method, teachers presents a story from social life. Then students playing certain roles with the contents of the story in a drama. Sociodrama is meant is a way of teaching by dramatizing the form of behavior in social relationship (Sumiati and Asra, 2002:100).

\section{Technical Application Of Sociodrama Method}

There are some instructions for being able to apply this method, there are simple revealing and there are also detail explained of the instructions. But in principle it's instructions are the same. In its application, can be developed separately by the concerned.

\section{a. Preparation Phase}

In this phase, Engkoswara (in Basyiruddin, 2013; 52) said that before doing the Sociodrama required the determination of the principal problems that will be dramatized first, specifying the players, and prepare the students as audiences who watch of the story. The problem will be dramatized selected gradually, starting from a simple problem and proceed with the next meetings are rather difficult and more varied. And also keep in mind, the problems will be set should attract the attention of students as well as the problem situation will be set should correspond to the age level of the students (Sudjana. 2002:85).

\section{b. Phase of Implementation.}

After the phases in the preparation are completed, students are welcome to dramatize problems requested for approximately 4 to 5 minutes based on their own opinions and initiatives.

\section{c. Phase of Follow-up}

As Sudjana has revealed that when the Sociodrama has ended, then needed a follow-up required. Students conduct discussions as one of the alternatives. Engkoswara (in Basyiruddin, 2013:53) reveals that the Sociodrama is a method of teaching, so in practice not only ended in the implementation of the 
dramatization, but should be continued with the questioning, discussion, criticism, or analysis of the problem. And if deemed necessary, other students are allowed the role repeat the role better. As one of the follow-up effort students can do the activity rate or provide a response to the implementation of the sociodrama and gives the opportunity to students to make the conclusion of the sociodrama results (Basyiruddin, 2013:95)

The following detail steps the application of the method of sociodrama learning to stimulating the development of attitudes, knowledge and skills of the students:

a. When the new Sociodrama method applied in teaching, then the teacher should explain it in advance of its implementation techniques, and determine among students the right to play certain characters, then simply played in front of the class.

b. Implement situation and problems will be played and also told the events and the background of story to be played in accordance with the material to be delivered.

c. scene Setting and mental readiness can be done in such a way that it really could build more interesting interactions.

d. After Sociodrama it was in the climax, then teachers can stop the drama. This is intended so that the possibilities of solving the problem can be solved in General, so that the audience (students who observed) there is a chance to argue and judge sociodrama played. Sociodrama can also be stopped when deadlocked.

e. Students are given the opportunity to provide comments, conclusions or notes the suitability of course sociodrama with the material being discussed.

f. Teachers receive all input, from students and provide an appropriate summary of the material illustration through the Sociodrama method.

g. Harmonizing the understanding of the concepts described in the problem solving/problem related to the learning material.

h. After the activity is completed, the teacher could give an example of a matter that must be resolved with the use of the concept as it has been practiced by the students through the Sociodrama method. It can evaluated whether the method succeeded or not, which the indications can be seen through the capabilities of integrating the concept was exhibited into problem to be solved.

\section{Sociodrama Methods, Stimulating Development of attitudes, knowledge and skills of Students in excellent service learning}

There is some material in the subjects of excellent service, among which are the following: a Personal Appearance Standards), b) principles of excellent service, c) provide assistance to customers, and d) Communicate with customers. There is some material of knowledge in excellent service that is difficult to understand by students when the teacher explains the method of regular lectures. This is because some of the material requires deep understanding and imagination of students to be able to imagine the real state of affairs in the field.

The Sociodrama method in this article is a modification of the stages presented by (Basyiruddin, 2013) i.e. characterization stages are assigned by a group of actors to a sub material, and other material is played by other groups that 
have been organized by the students themselves. For example the following is a step-by-step method of Sociodrama in the material provides assistance to customers:

\section{a. preparation}

1) Define the topics or problem as well as the goals to be achieved in learning, the topic "how to resolve customer complaints". Learning objectives to be achieved are students can understand and practise how to deal with customer complaints.

2) Motivates students and gives an overview of the problem in the situation to play, for example, a customer came to the store to deliver the complaint, then the students are given an overview of what is done by the waitress and customers in those situations.

3) Teachers compose/prepare scenarios to be displayed.

4) Pointing to some students to study the scenario two days or several days before teaching and learning activities to prepare for the roles contained in the scenario.

5) The teacher formed the Group of students who are members of 5 people or according needs.

\section{b. implementation}

1) Calling students who have been appointed to play of scenarios that were already prepared in advance.

2) Each student sitting in each group, while attention to observing the scenario that is being exhibited.

3) Sociodrama began to be played by a group of actors.

4) Other students as an observer is following with great attention.

5) Teachers provide assistance to actors who are getting in trouble.

\section{c. Closing.}

1) After stages are finisished, each student is given a paper as a worksheet to discuss the scenarios. For example, assessing the role of playing, looking for weaknesses and advantages of the role or the plot/storyline.

2) Each group delivering results and conclusion.

3 ) The teacher gives the conclusion in general or evaluate all activities.

4) Evaluation as feedback of learning process.

In the material provides assistance to Customers there is a sub chapter how to resolve customer complaints. Some way to consider when addressing customer complaints, it is also useful to create a role scenario in the Sociodrama method, as follows:

a. service officer do not make promises just for the sake of pleasing customers because the fatal in future.

b. Customers Sometimes angry when complaints. The officer must refrain angry.

c. If there are customers who always complain, the officers must be patient and approach specifically

d. By opening the dialog conversations are fine, there is no problem that cannot be resolved

e. Face customers complaints wisely, don't get carried away the emotions. 
f. Listen with full attention to all customer complaints, as far as possible on the full atmosphere of familiarity.

g. quietly, avoid anger and blame the customer, do not argue with customer.

h. bring customers who are angry to somewhere so that other customers cannot hear or know about it.

i. Don't offend the customer pride.

j. Make notes, write down each customer complaints in detail.

$\mathrm{k}$. Tell customers what we doing to them, an offer some options, do not contain a appointments just for fun the customers when such appointments outside of authority.

b. To resolves the complaint, determine a time, try as soon as possible and on time.

m. Give a sense of sympathetic and feel the difficulties that befell the customers.

n. Respond customer complaints well, include the sayings sorry sincerely and promised to improve the service.

o. Contact customer and ask if the complaint is already handled quite satisfactory, then said thank you.

When students are able to do things above, so expected learning goals can be achieved. In the sociology method, the affective aspect of motor more aroused than in cognitive aspects, related to the life of social relations. Material provide assistance to customers in the subjects of excellent service in accordance with the method of learning Sociodrama, because facts, values, conflicts that occur in the environment of social life.

Through the game Sociodrama on learning excellent service, students are invited to recognize, feel a situation so that they can find the right attitudes and actions in the same situation. This is effort of anticipation in a society who started missing values and morality, attitude education is the right momentum to rise (Koesoma, 2010:132-133).

"Plato menekankan pentingnya pengalaman masa dini dalam pembentukan karakter, akan tetapi ia juga menyatakan bahwa pengalaman dikemudian hari juga dapat mengubah karakter" (Santrock, 2003:9). Thus, the attitude is a matter that needs attention more broadly because of education are the children spend most of their time, so it is expected that the educational of attitudes or characters can to fortify themselves children from strong currents of globalization. With this attitude education expected emotional intelligence of children able to grow in harmony with his intellectual intelligence.

implementation of Curriculum 2013 expect students not only memorize of the theory, but is expected to be able to apply in order to obtain the knowledge that much that the quality of education to be good. Direct experience, observation, participation even demonstrations will make students more optimally in achieving learning. Optimal learning will produce a lot of knowledge. It's different when a student only gains knowledge from books or listen to the teacher.

Direct practice to be important subjects of Excellent Service in order to stimulate creativity and imaginative students. Direct practice is meant for learners to imagine and feel as though they are in real situations when the excellent service is done. after students can imagine, the next step isto do the teacher is to guide 
learners to not just imagined, but it can do excellent service in accordance with the situation in the field.

By applying models of Sociodrama learning, teachers are expected to enhance the skills of students in the subjects of excellent service. Of the three steps of sociodrama method i.e., preparation, execution and closing, stages the most instrumental in improving the skills of the students against the material "provides assistance to customers" is at the stage of implementation. In this stage, the student is required to play the role of handling customer complaints well.

Utami (2014) in research, applying Sociodrama methods/role playing, on subjects Do excellent service to the students of Class XI Marketing SMK Negeri 3 Semarang and concluded that learning by using method of Sociodrama learning can improve the skills of students in providing assistance to customers. With the percentage of student skills in the cycle learning I i.e. $70 \%$ with a good category and on cycle II rising to $92.5 \%$ with very good category. This research is in line with the discussions, model of Sociodrama learning can improve the skills of students in doing excellent service.

The Results of research by Purwanto (2014) concluded that the application of the Sociodrama method/Role Playing can improve the ability on linguistic aspects of the students class VIII A SMP Negeri 3 Paron 2013/2014. This research in accordance with the discussion of student skills that can be improved through the application of the learning model of role playing. Boal 1985, Cossa, Ember, Graver and Hezelwood,1966; argues that sociodrama can be a tool in improving the social and political awareness, address the critical issues with other people, to understand the basic theory and practice of the skills or the involvement of counsellors in the process help change the psychological behavior of a person. Sociodrama describe as Theatre technique (role playing/emulate the role in real life) is used in an educational setting and practice and can also be used as a form of therapy in the training.

Aspects of the knowledge, skills and attitudes play a role to create quality human resource, skill without knowledge will not achieve optimum results so instead. To achieve the best quality skills and knowledge need to be accompanied by education of attitude so that the youth and the youth of this country the smart not only intellectually but also emotionally intelligent and have skills so that is able to face the challenges that come from the outside world. Based on the description above, it can be seen that the model of learning Sociodrama can be applied in training excellent service because these models support the material. According to some research, actually not only on subjects just excellent service learning models can be applied, but it can on other subjects that the material is relevant to the learning models. It's just that teachers must be more creative to modify and combine learning model to deliver the other material. It is aimed for the learning process can be run properly, smoothly, fun, and most importantly the purpose of learning can be achieved.

\section{CONCLUSION}

Sociodrama learning model can stimulate and increase the development of attitudes, knowledge, and skills of students in the subjects of excellent service 
because of this learning model invites students to practice directly how to provide excellent service to customers. Sociodrama learning model is a learning that requires students to always active and key role in the learning process. The use of this learning model is aimed to make the learning process becomes more fun and active so that students can be more motivated in learning materials given by the teacher.

\section{REFERENCES}

Basyiruddin, U. 2003. Metodologi Pembelajaran Agama Islam. (Jakarta: Ciputat pers.

Djamarah, S.B dan Zain, A. 2010. Strategi Belajar Mengajar. Jakarta: PT Rieneka Cipta.

Koesoma, Doni. 2010. Pendidikan Karakter: Strategi Mendidik Anak di Zaman Global. Jakarta:Grasindo.

Maryati, Kun \& Juju Suryawati. 2006. Sosiologi. Jakarta: Esis.

Purwanto. 2014. Penggunaan Metode Role Playing untuk Meningkatkan Kemampuan Berbicara. Diakses dari http://jurnal-induksi.com/edisi1 /penggunaan-metode- role-playing-untuk-meningkatkan-kemampuanberbicara-siswa-kelas-viii-asmp-negeri-3-paron/ pada tanggal 2 Mei 2017.

Ramelan, R. 2008. "Bahasa dan Kognisi". Wacana Jurnal Ilmu Pengetahuan dan Budaya. Vol.10, 74.

Santrock, W Jhon. 2003. Adolescense Perkembangan Remaja. Jakarta: Gramedia.

Sudjana. 2002. Dasar-Dasar Proses Belajar Mengajar. (Bandung: Sinar Baru Algensindo).

Sumiati dan Asra, M.Ed . 2007. Metode Pembelajaran. Bandung : Wacana Prima.

Undang-Undang No 20 Tahun 2003 Tentang Sistem Pendidikan Nasional. Jakarta: Depdiknas.

Utami, E.S. \& Kusumantoro (2014). Peningkatan Keterampilan Siswa Memberikan Bantuan Kepada Pelanggan dengan Metode Role Playing Kelas XI Pemasaran. Economic Education Analysis Journal, EAJ 3(1) (2014). Diakses dari http://journal.unnes.ac.id/nju/index.php/DP/article/download/352/334. Pada tanggal 5 mei 2017.

Winkel, W.S. 2005. Psikologi Pengajaran. Jakarta : PT.Gramedia Pustaka Utama. 